Bioscientia Medicina: Journal of Biomedicine \& Translational Research

Journal Homepage: www.bioscmed.com

\title{
Gendola Leaf Ethyl Acetate Fraction (Basella rubra Linn) Reduces Spermatozoa Motility and Viability in Vitro
}

\section{Lusia Hayati $^{*}$, Joko Marwoto', Septi Purnamasari¹, Yuni Fitriayanti²}

${ }^{1}$ Department of Medical Biology, Faculty of Medicine, Universitas Sriwijaya, Palembang, Indonesia ${ }^{2}$ Department of Medical Biology, Faculty of Medicine, Universitas Sriwijaya, Palembang, Indonesia ${ }^{3}$ Department of Medical Biology, Faculty of Medicine, Universitas Sriwijaya, Palembang,, Indonesia

${ }^{4}$ Master Program in Biomedical Sciences, Faculty of Medicine, Universitas Sriwijaya, Palembang, Indonesia

\section{A R T I C L E I N F O}

\section{Keywords:}

Ethyl acetate

Spermatozoa

Motility

Phenol

Viability

\section{*Corresponding author: \\ Lusia Hayati \\ E-mail address: \\ lusia_hayatioo@yahoo.com}

All authors have reviewed and approved the final version of the manuscript.

\begin{abstract}
A B S T R A C T
Background. The use of plants as anti-fertility in men has been done to reduce side effects. The Gendola plant is one of the Basellaceae family plants, which is a natural medicinal plant in Indonesia. Gendola leaves contain phenol compounds, flavonoids, tannins, steroids and triterpenoids which can have cytotoxic activity. This study aims to determine the in vitro anti sperm activity of the ethyl acetate fraction of Gendola leaves on male spermatozoa. Methods. This study is an experimental laboratory in vitro study using male sperm preparations. The sample used was 20 men for each group, both the group was given the gondola leaf fraction and the control group. The treatment group was given ethyl acetate fraction of Gendola leaves (Basella rubra Linn.) With a concentration of $0.05 \%$ for 5, 10 and 15 minutes, the viability and motility of sperm were calculated. Data analysis was performed using the Mann Whitney test $(\mathrm{p}<0.05)$ using SPSS release for Windows software. Results. The results showed that the ethyl acetate fraction affected the motility and viability of spermatozoa. When compared with the control group, the motility treatment group obtained was classified as non-progressive. In the treatment group, the viability of spermatozoa was significantly different at minute 5 , minute 10 and minuted $15 \mathrm{p}$ $<0.05$ ). Conclusion. Ethyl acetate fraction has potential as an anti sperm in reducing sperm motility and viability.
\end{abstract}

https://doi.org/10.32539/bsm.v5i3.212

\section{Introduction}

Fertility regulation which consists of contraception and management of infertility is an essential component for the reproductive health of both men and women. ${ }^{1}$ Effective methods for infertility have been further investigated including hormonal, chemical and immunological methods.2,3 However, in reality, these methods have various side effects such as obesity, gastric problems, breast and cervical cancer. To overcome these side effects, the use of plants as antifertility in male reproductive function is used as an alternative. ${ }^{2}$

Sperm viability and motility are part of the semen analysis to assess semen quality and fertility success. If there is a decrease in the percentage of viability and sperm motility below typical values, there will also be a decrease in fertility ${ }^{1,4}$.

Sperm viability is the vitality of sperm. Examination of sperm viability can be used as an indicator of decreased sperm cell membrane integrity. With Eosin Y staining, the dead sperm cells will be purple-red due to the damage to the sperm cell membrane so that the dye is absorbed into the sperm cells, and the living cells are not stained. Determination of viability (living sperm cells) in per cent (\%).1,4

Sperm motility is the motility of sperm to fertilize an 
egg. Sperm motility was measured by observing the speed of sperm motion and categorized into progressive motility (PR), non-progressive motility (NP) and immotility (IM). The percentage of the number of motile sperm was determined by adding the $\% \mathrm{PR}+\mathrm{NP}$ category. ${ }^{1,4}$

Sperm viability and motility are part of the semen analysis to assess semen quality and fertility success. If there is a decrease in the percentage of viability and sperm motility below average, there will also be a decrease in fertility ${ }^{1,4}$.

Currently, the government has implemented the family planning program. However, in reality, the program has not been able to run optimally because men's participation in family planning is still low. This is due to the unavailability of safe family planning facilities for men. In order to increase men's participation in family planning, efforts should be made to develop male contraceptive methods using alternative materials from natural ingredients in Indonesia. 5,6

The gendola plant is one of the Basellaceae family plants, which is a natural medicinal plant in Indonesia. ${ }^{7}$ In vitro studies have shown that gendola fruit extract has vigorous cytotoxic activity against cervical cancer cells. ${ }^{8}$ The content of chemical compounds in gendola leaves, namely saponins, flavonoids, phenols, $\beta$-cyanin and 7,4 '-di-ortho methyl kaempferol.9-13 Apart from having cytotoxic activity, several studies on gendola plants have pharmacological activity as antifungal, anticancer, antioxidant, antiviral, anti-inflammatory, antiulcer, anti-cholesterol effect, antimicrobial, anti-hypoglycemic, gastroprotective, androgenic effect, haematological and biochemical parameters, immunomodulatory activity. ${ }^{13,14}$ Of these studies, this study is one of the first to test the gendola leaf fraction as an anti-sperm in men in vitro. This study will assess the potency of the ethyl acetate fraction of gendola leaves on the motility and viability of semen in men in vitro. From the results of this study, it is hoped that Gendola leaves can be used as an anti-sperm and can be used as an alternative contraceptive for men.

\section{Methods}

This study is an experimental laboratory in vitro study using male sperm preparations. The sample used was 20 cement samples from men aged 25 to 40 years who were willing to become respondents and came to the Medical Biology Laboratory, Faculty of Medicine, Universitas Sriwijaya.

Semen preparations are taken by masturbating after previously the respondent was asked to perform abstinence for at least two days and not more than seven days. The product is collected in a clean, widemouthed glass container. The criteria for semen taken as a sample were semen that was classified as normal, namely a minimum sperm count of 20 million / $\mathrm{ml}$, a minimum semen volume of $2 \mathrm{ml}$, sperm motility $>32 \%$ and sperm viability $>60 \%$. This study has received the approval of the Ethics Committee for Medical and Health Research, Faculty of Medicine, Sriwijaya University (Protocol Number: 131-2020).

\section{Materials}

The tools used in this research are a spectrophotometer, analytical balance, Bunsen lamp, blender, oven, Erlenmeyer flask, beaker glass, flacon bottle, incubator, petri dish, glass beaker, micropipette, test pipette, water bath and writing instruments. The test materials used in this study were Gendola leaves obtained in the Ogan Ilir Scales area, 20 male sperm, 96\% ethanol, ethyl acetate solution, n-hexane solution, DMSO, distilled water, $0.5 \%$ eosin dye.

\section{Gendola leaf extraction and fractionation}

Gendola leaves are dried and blended until smooth to obtain dry powder (simplicia). Gendola leaf extract was made by the maceration method using $96 \%$ ethanol solvent. The simplicia was then immersed in $1000 \mathrm{ml}$ of $96 \%$ ethanol, then let it stand for 48 hours and filtered. The extract was obtained and evaporated using a rotary evaporator with a water bath temperature of $80^{\circ} \mathrm{C}$ until a thick extract was obtained. The thick extract was dried with a hairdryer until a dry extract was obtained. ${ }^{8}$ The gendola leaf extract was then fractionated with ethyl acetate in a ratio of 1: 1 
using a separating funnel. The ethyl acetate fraction is then filtered, concentrated using a rotary evaporator and dried with a hairdryer.

\section{In vitro anti sperm activity test}

The anti sperm activity test was carried out by dropping $15 \mu \mathrm{l}$ of the ethyl acetate fraction of Gendola leaves with a concentration of $0.05 \%$ into a petri dish. Then added $0.5 \mu 1$ of cement preparation and let it stand for 5, 10 and 15 minutes. To observe sperm motility, a mixture of $10 \mu \mathrm{l}$ of sperm preparation was placed in a slide with a coverslip. Observation of sperm motility was carried out under a microscope with a magnification of 400 times (magnification of 40 times the objective lens and ten times of the ocular lens) counting 100 sperm. ${ }^{14}$ To observe the viability of cement, $10 \mu \mathrm{l}$ of the cement mixture was placed in a glass slide, then the preparation was dropped with $0.5 \%$ eosin Y. After the preparation is homogenized, cover with a cover glass. After waiting for about 10 seconds, the sperm viability was observed under a microscope with a 200 times magnification. For the control treatment, sperm motility and viability were observed directly under a microscope with a magnification of 400 times (magnification of 40 times the objective lens and ten times of the ocular lens) with a variety of times of 5 minutes, 10 minutes, and 15 minutes counting 100 sperm.

\section{Spermatozoa motility test}

Sperm motility was measured by observing the speed of the sperm in a slide covered with a coverslip (22 x $22 \mathrm{~mm})$ under a 400 times magnification microscope. The number of rapidly motile sperm is calculated based on the criteria of progressive motility $(\mathrm{PR})$ : active mobile spermatozoa, non-progressive motility (NP): all other patterns of motility in the absence of progress, for example, swimming in small circles and Immotility (IM): none movement. Observations were made on 100 sperm, then repeated one time the results were averaged. Sperm motility is expressed in per cent. The percentage of the number of motile sperm is determined by adding the $\mathrm{PR}+\mathrm{NP}$ categories, divided by the number of $\mathrm{PR}+\mathrm{NP}+\mathrm{IM}$ categories then multiplying by $100 \%$.

\section{Spermatozoa viability examination}

In order to observe the viability of sperm, Eosin Y dye was used which was dropped on the tip of the object-glass, then added one drop of cement $(10 \mu \mathrm{l})$, homogenized and made smear preparations. Observation of the viability of spermatozoa was carried out on 100 spermatozoa cells under a light microscope with a 400x magnification, the observation was that the living spermatozoa would not be stained with Eosin Y, but the dead spermatozoa would have a purplish red colour due to damage to the plasma membrane of the spermatozoa cells. The determination of the viability of spermatozoa is expressed in per cent $100 \%$.

Percentage of spermatozoa viability=(living spermatozoa)/(the total of living and dead spermatozoa) $\mathrm{x} 100 \%$

Analysis of spermatozoa quality data was tested for normality of data distribution by Shapiro Wilk. The results of the above test showed that only the control group was not normally distributed ( $\mathrm{p}<0.05)$, while in the treatment group the viability of the $5^{\text {th }}, 10^{\text {th }}$ and $15^{\text {th }}$ minutes was normally distributed. In order To see the difference in sperm viability between groups, the fraction was analyzed using repeated measure tests to see the comparison of sperm viability between the treatment group and the control group analyzed using the Mann Whitney test.

\section{Result}

Table 1 shows the phytochemical test on the ethyl acetate fraction; the tannin content is obtained. Table 2 shows the mean percentage of spermatozoa motility and viability in the control and treatment groups. In the treatment group, non-progressive motility of spermatozoa was found, so that in the treatment group, only viability testing was carried out at the $5^{\text {th }}, 10^{\text {th }}$ and $15^{\text {th }}$ minutes. 
Table 3 shows that there is a difference in the viability of the $5^{\text {th }}$ minute compared to the $10^{\text {th }}$ minute $(p$-value $=0.002)$ and the $5^{\text {th }}$ minute viability to the $15^{\text {th }}$ minute $(\mathrm{p}$-value $=0,000)$, during the 10-minute viability as compared to the $10^{\text {th }}$ minute, indicating the results were not significantly different $(\mathrm{p}$-value $=$ 0.441). Table 4. Shows that there are significant differences between groups $(p<0.05)$. This suggests that the ethyl acetate fraction of Gendola leaves can reduce sperm viability in vitro.

Table 1. The results of Phytochemical Screening Test for Ethyl Acetate Fraction of Gendola Leaves (Basella rubra Linn.)

\begin{tabular}{lc}
\hline Chemical compound & Ethyl acetate fraction \\
\hline Alkaloids: Dragendorf & - \\
Alkaloids: Mayer & - \\
Flavonoids & - \\
Steroids & - \\
Tannins & + \\
\hline
\end{tabular}

Table 2. Mean motility and viability of spermatozoa in each group

\begin{tabular}{cll}
\hline Variable & Control (\%) & Treatment (\%) \\
\hline Motility & $78.15 \pm 14.59$ & 0 \\
Viability & $79(15-92)$ & (Non progressive) \\
5th minute viability & - & $38.70 \pm 19.53$ \\
10th minute viability & - & $19.20 \pm 9.18$ \\
15th minutes viability & - & $16.05 \pm 8.64$ \\
\hline
\end{tabular}

Table 3. Results of Repeated Measure Test in the Spermatozoa Viability Group

\begin{tabular}{ccc}
\hline \multicolumn{1}{c}{ Time } & \multicolumn{1}{c}{ Time } & $\begin{array}{c}\boldsymbol{p} \\
\text { value }\end{array}$ \\
\hline $5^{\text {th }}$ minutes & $10^{\text {th }}$ minutes & 0.002 \\
& $15^{\text {th }}$ minutes & 0.000 \\
$10^{\text {th }}$ minutes & $15^{\text {th }}$ minutes & 0.441 \\
\hline
\end{tabular}

Table 4. Mann Whitney test results in the treatment group and the control group

\begin{tabular}{lcccc}
\hline Variable & $\mathbf{n}$ & $\begin{array}{c}\text { Control } \\
\text { Median }\end{array}$ & $\begin{array}{c}\text { Treatment } \\
\text { Mean } \pm \text { SD }\end{array}$ & P value \\
\hline V-5 & 20 & $79(15-92)$ & $38.70 \pm 19.53$ & 0.000 \\
V-10 & 20 & $79(15-92)$ & $19.20 \pm 9.18$ & 0.000 \\
V-15 & 20 & $79(15-92)$ & $16.05 \pm 8.64$ & 0.000 \\
\hline
\end{tabular}

\section{Discussion}

The results showed that the ethyl acetate fraction of $0.05 \%$ Gendola leaves could decrease the motility and viability of spermatozoa. Determination of spermatozoa motility based on three criteria, namely progressive motility (PR), non-progressive motility (NP) and immotility (IM). The results showed that spermatozoa motility in the treatment group was categorized as nonprogressive. One of the conditions of the motility of the spermatozoa can be caused by the morphology of the 
spermatozoa. The tail of the spermatozoa is composed of an axonemal which functions as a means of movement of the spermatozoa. The constituent axoneme consists of a central pair of microtubules and is surrounded by nine pairs of microtubules on the outside. The outer microtubules are composed of dynein protein. Dynein protein can hydrolyze ATP which is used for sperm motility because the formation of Reactive Oxygen Species (ROS) causes a decrease in ATP production in the mitochondria so that dynein protein cannot hydrolyze ATP and results in disruption of spermatozoa motility. ${ }^{11}$

In previous research, it was stated that the seed and leaf extracts of the Gendola plant (Basella alba L) showed anticancer activity. ${ }^{6}$ steroids, saponins, and phenols. In this study, the decreased motility and viability of spermatozoa was probably due to the compounds contained in the ethyl acetate fraction of gendola leaves. The content of the chemical compounds contained in this study was obtained tannins. The potential of tannins as an anticancer is thought to be the same as the potential for tannins in reducing the motility and viability of spermatozoa. In anticancer tannins act as anti-proliferative that act at the cellular level by blocking the "S" phase of the cell cycle10. Also, tannins also play a role in the process of forming cell membranes, accelerating protein deposition and can bind to macromolecules so that the cell wall or cell membrane can shrink, thereby disrupting the permeability of the cell itself. Due to disruption of permeability, cells cannot carry out living activities so that their growth is stunted or even dies 9 .

There are two ways of working of anti-fertility compounds, namely cytotoxic effects and hormonal effects. This method of action is also thought to cause a decrease in the motility and viability of spermatozoa. If a compound in a plant is toxic, then the cells exposed to the compound can die, especially cells that are undergoing development. If the compound has a hormonal effect, then the compound will bind to the receptors found in the reproductive organs where hormones are supposed to be occupied. It is suspected that tannins are present in the gendola leaf fraction causes the same thing, which affects the permeability of the sperm cell membrane, so that the transport of nutrients or nutrients through the cell membrane can be disrupted. As a result, cell metabolism in producing energy will also be disrupted and reduce the motility and viability of spermatozoa. 4

\section{Conclusion}

Based on the results of the research that has been done, the gendola leaves can have the potential as an anti-sperm. This fraction of the leaves can reduce the motility and viability of spermatozoa. The content of this plant fraction that is useful as an anti-sperm is tannins.

\section{Acknowledgement}

The author would express their sincere gratitude to LPPM Sriwijaya University for providing the 2020 PNBP Research fund.

\section{References}

1. Allag IS and Rangari K: Extragenomic action of steroids on spermatozoa: Prospects for regulation of fertility. Health Population 2002;25:38-44.

2. Bhowmik D, Umadevi M, and Kumar PKS and Duraivels: Medicinal Plants with Potential Antifertility Activity. Journal of Medicinal Plants Studies 2013;1:26-33.

3. Gupta RS and Sharma R: A review on medicinal plants exhibiting antifertility activity in males. Natural product radiance 2006;5:389-410.

4. Handayani M, Gofur A, Maslikah SI. 2014. Potensi Daun Pulutan sebagai Bahan Antifertilitas Manusia.

5. Herdiningrat, S. 2002. Efek Pemberian Infusa Buah Manggis Muda (Garcinia Mangostana Linn) terhadap Spermatozoa Mencit (Mus musculus). Majalah Andrologi Indonesia. 10 (4): 130 .

6. Islam MS, Rahi MS, Jahangir CA, et al. In Vivo Anticancer Activity of Basella alba Leaf 
and Seed Extracts against Ehrlich's Ascites Carcinoma (EAC) Cell Line. Evid Based Complement Alternat

Med.2018;2018:1537896. Published 2018

Nov 19. doi:10.1155/2018/1537896

7. Kemenristek. 2002. Tanaman Obat. Ristek (Riset dan teknologi) www.warintek.hol.es

8. Kumar SS, Manoj P, Giridhar P, Shrivastava R. \& Bharadwaj M. 2015. Fruit Extracts of Basella rubra that are Rich I Bioactives and Betalains Exhibit Antioxidant Activity and Cytotoxicity Against Human Cervical Carcinoma Cells. Journal of Functional Foods. 15:509-515.

9. Merck Index. An encyciopedia of Chemical Drug. 9 Ed. Ney Jersey.

10. Mustafida, R Y., Al Munawir., Dewi, R. 2014. Efek Anti Angiongenik Ekstrak Etanol Buah Mahklota Dewa (Phaleroa mecrocarpa (Scheff)
Boerl.) Pada membran Korea Alantolis (CAM)

Embrio ayam. e-jurnal pustaka kesehatan.2(1);4-8

11. Purwaningsih, E. 1996. Morfologi Spermatozoa Adakah Kaitannya dengan Kehamilan. Jurnal Kedokteran YARSI, 4 (1), 54-65.

12. Ratna, dkk. 2014. Aktivitas Antibakteri Ekstrak dan Fraksi Daun Kersen (Mutingiacalabura). Fakultas Farmasi, Universitas Muhammadiyah Surakarta.

13. Singh M, Kumari R, Nandini D.\& Kotecha M. 2016. Preliminart Phytochemical Screening of Basella rubra Linn. Journal of Pharmacognosy and Phytochemistry. 5 (4): 224-226.

14. World Health Organization (WHO). 2010. WHO Laboratory Manual for the Examination and Processing of Human Semen Ed 